\title{
An Empirical Analysis of the Impact of Economic Opening on Hubei's Green Economy Efficiency*
}

\author{
Zhaoyang Wang ${ }^{1,2}$
}

(1 Jianghan university School of business, Hubei, Wuhan, P.R China 430056;

2 Manufacturing Industry Development Research Center on Wuhan City Circle, Wuhan, Hubei, P.R China 430056)

mornsun78@126.com

\section{Keywords: Economic Openness; Green Economy Efficiency; Super Efficiency DEA; VAR Model}

\begin{abstract}
Taking data of Hubei's foreign trade openness, foreign investment openness and the green economic efficiency in 1986-2015 as sample, based on VAR model, this paper empirically studies on the interaction among these variables. The results show that there is a long-term equilibrium relationship between the foreign trade openness, the openness of foreign investment and the green economic efficiency of Hubei. The foreign trade openness has a continuous promotion effect on the growth of green economic efficiency in Hubei Province, but the foreign investment openness has shown the effect of restraining production in Hubei's economic efficiency, and the latter is only the promotion effect. "The hypothesis of pollution heaven" is again verified in Hubei.
\end{abstract}

\section{Introduction}

Since the reform and opening up, Hubei's economy has made great progress. The regional GDP has increased from 15.1 billion yuan in 1978 to 295.501 billion yuan in 2015. At the same time, Hubei's position in the national economy has also been rising. By 2015, the proportion of Hubei's GDP to the country's gross domestic product reached $4.37 \%$, and its economic openness level has also been strengthened. The dependence on foreign trade and foreign investment respectively increased from 0.0673 and 0.0010 in 1986 to 0.0961 and 0.0189 in 2015. The rapid growth of the economy is accompanied by high environmental pollution and high energy consumption (1). In recent years, the total amount of wastewater discharge and energy consumption in Hubei Province have risen in all other years except for the decline in individual years. Although the annual average growth rate of sulfur dioxide emissions is negative, the average annual growth rate of smoke dust emissions and industrial solid waste emissions in exhaust gas is as high as $5.43 \%$ and $7.97 \%$. (2) It can be seen that high pollution and high energy consumption are the distinctive features of Hubei's rapid economic growth.

In the report of the 19th National Congress of the Communist Party of China, General Secretary $\mathrm{Xi}$ clearly pointed out that "the development concept of innovation, coordination, green, openness, and sharing must be unswervingly implemented", put forward the economic transformation idea of "promoting economic development quality change, efficiency change, power change, and improving economic efficiency", and required China to "actively participate in and promote the process of economic globalization and develop a higher level of open economy." (3) Under the dual constraints of environment and energy, how to develop an open economy and promote the economy to a higher level is the core issue that needs to be resolved today. This paper uses the green economy efficiency to measure the level of economic development in Hubei Province under the environment and energy constraints, measures the degree of economic openness by using

\footnotetext{
About the author: Wang Chaoyang (1978.9-), male, Wuhan, Hubei, associate professor of Jianghan University, Ph.D. in Economics, research direction: international trade, econometrics

(1) See "Hubei Statistical Yearbook"

(2) Due to limited space, specific data on environmental pollution and energy consumption in Hubei Province are not listed.

${ }^{3}$ See the "Nineteenth National Report"
} 
foreign capital openness and foreign trade openness, and uses the vector autoregressive model (VAR model) to systematically analyze the relationship between the above three economic variables., in order to provide a theoretical reference for the development of high-level open macroeconomic policies in Hubei Province.

\section{Variable Selections and Descriptions}

\section{Hubei's Green Economy Efficiency}

DEA and super-efficiency DEA models were used to evaluate the green economy efficiency of Hubei. In recent years, the DEA method and the super-efficiency DEA method (hereinafter referred to as SE-DEA) have been widely used at home and abroad, and the theoretical principle will not be described in detail.

On the basis of researching and drawing on the existing achievements at home and abroad, three categories of indicators: economic, resource and environment are selected as the basis for the evaluation of Hubei's green economy efficiency.

(1) Resource indicators: According to the connotation of green economy efficiency and the availability and typicality of data, this paper selects the most representative indicators of energy consumption, the number of employees in the whole society and the physical capital stock as resource input indicators. For the capital stock K, this paper uses the method of Shan Haojie (2008) to estimate the capital stock of Hubei Province from 1986 to 2015, calculated according to the 1986 constant price. The energy consumption and the number of employees in the whole society are from the Hubei Statistical Yearbook.

(2) Environmental indicators: Select the most representative indicators of wastewater discharge exhaust emissions and solid waste discharge as environmental indicators, referred to as "three wastes". "Three Wastes" as the "bad" output in economic activities, this paper incorporates this "bad" output as an input into the data envelopment analysis model in the DEA model.

(3) Economic indicators: Select GDP as the output indicator. In order to eliminate the error caused by regional differences in regional GDP, Hubei's annual GDP is based on the real GDP obtained by gradual reduction in 1986. The green economy efficiency evaluation index system of Hubei is shown in Table 1.

Table 1 Green Economy Efficiency Evaluation Index System of Hubei

\begin{tabular}{|c|c|c|c|c|}
\hline Indicator Type & Indicator Category & Specific Indicator & Unit & Symbol \\
\hline \multirow{7}{*}{$\begin{array}{l}\text { Input } \\
\text { Indicators }\end{array}$} & \multirow{3}{*}{ Resource Indicators } & $\begin{array}{l}\text { Number of employees in } \\
\text { the society }\end{array}$ & Year & $\mathrm{L}$ \\
\hline & & Material capital stocks & 100 million & $\mathrm{K}$ \\
\hline & & Energy consumption & $\begin{array}{l}10,000 \text { tons of } \\
\text { standard coal }\end{array}$ & $\mathrm{E}$ \\
\hline & \multirow{4}{*}{$\begin{array}{l}\text { Environmental } \\
\text { indicators }\end{array}$} & $\begin{array}{c}\text { Total wastewater } \\
\text { discharge }\end{array}$ & 10,000 tons & WATER \\
\hline & & $\begin{array}{c}\text { Sulphur dioxide emissions } \\
\text { in exhaust gas }\end{array}$ & 10,000 tons & $\mathrm{SO} 2$ \\
\hline & & $\begin{array}{l}\text { Smoke and dust emissions } \\
\text { in exhaust gas }\end{array}$ & 10,000 tons & DUST \\
\hline & & $\begin{array}{l}\text { Industrial solid waste } \\
\text { production }\end{array}$ & 10,000 tons & SOLID \\
\hline $\begin{array}{l}\text { Output } \\
\text { indicators }\end{array}$ & economic indicators & actual local GDP & 100 million & RGDP \\
\hline
\end{tabular}


Table 2 Green economy efficiency of Hubei Province based on SE-DEA method measurement from 1986 to 2015

\begin{tabular}{|c|c|c|c|c|c|}
\hline Year & $\begin{array}{c}\text { Super } \\
\text { efficiency }\end{array}$ & CRSTE & VRSTE & SCALE & $\begin{array}{c}\text { Scale } \\
\text { remuneration }\end{array}$ \\
\hline 1986 & 0.8976 & 0.8976 & 0.9798 & 0.9161 & irs \\
\hline 1987 & 0.8998 & 0.8998 & 0.9523 & 0.9449 & irs \\
\hline 1988 & 0.9497 & 0.9497 & 0.9724 & 0.9767 & irs \\
\hline 1989 & 1.0175 & 1.0000 & 1.0000 & 1.0000 & - \\
\hline 1990 & 0.9901 & 0.9901 & 1.0000 & 0.9901 & drs \\
\hline 1991 & 1.0299 & 1.0000 & 1.0000 & 1.0000 & - \\
\hline 1992 & 1.0391 & 1.0000 & 1.0000 & 1.0000 & - \\
\hline 1993 & 0.9996 & 0.9996 & 1.0000 & 0.9996 & irs \\
\hline 1994 & 1.0189 & 1.0000 & 1.0000 & 1.0000 & - \\
\hline 1995 & 1.0306 & 1.0000 & 1.0000 & 1.0000 & - \\
\hline 1996 & 1.6468 & 1.0000 & 1.0000 & 1.0000 & - \\
\hline 1997 & 1.0932 & 1.0000 & 1.0000 & 1.0000 & - \\
\hline 1998 & 1.0232 & 1.0000 & 1.0000 & 1.0000 & - \\
\hline 1999 & 0.9749 & 0.9749 & 0.9898 & 0.9849 & irs \\
\hline 2000 & 1.0503 & 1.0000 & 1.0000 & 1.0000 & - \\
\hline 2001 & 1.0102 & 1.0000 & 1.0000 & 1.0000 & - \\
\hline 2002 & 0.9569 & 0.9569 & 0.9811 & 0.9753 & irs \\
\hline 2003 & 0.9841 & 0.9841 & 0.9986 & 0.9855 & irs \\
\hline 2004 & 0.9989 & 0.9989 & 1.0000 & 0.9989 & irs \\
\hline 2005 & 1.0011 & 1.0000 & 1.0000 & 1.0000 & - \\
\hline 2006 & 0.9857 & 0.9857 & 0.9945 & 0.9912 & irs \\
\hline 2007 & 1.0029 & 1.0000 & 1.0000 & 1.0000 & - \\
\hline 2008 & 1.0370 & 1.0000 & 1.0000 & 1.0000 & - \\
\hline 2009 & 0.9851 & 0.9851 & 0.9893 & 0.9958 & irs \\
\hline 2010 & 1.2043 & 1.0000 & 1.0000 & 1.0000 & - \\
\hline 2011 & 1.0294 & 1.0000 & 1.0000 & 1.0000 & - \\
\hline 2012 & 1.0179 & 1.0000 & 1.0000 & 1.0000 & - \\
\hline 2013 & 1.0240 & 1.0000 & 1.0000 & 1.0000 & - \\
\hline 2014 & 1.0296 & 1.0000 & 1.0000 & 1.0000 & - \\
\hline 2015 & 1.0562 & 1.0000 & 1.0000 & 1.0000 & - \\
\hline mean & & 0.9833 & 0.9940 & 0.9891 & \\
\hline
\end{tabular}

Note: The CRSTE, VRSTE and SCALE respectively represent Comprehensive technical efficiency, pure technical efficiency and Scale efficiency; the irs, drs and - respectively represent increase, decrease and constant.

The first stage: it basically shows an upward trend from 1986 to 2001, except for the decline in individual years. It reaches its peak in 1996, and its super efficiency is 1.6468. With the further deepening of China's economic system reform, the introduction and implementation of a series of new development concepts such as "planned commodity economy", "socialist market economic system", "establishment of modern enterprise system", "tax-sharing system reform" and "housing marketization" and new economic policies have greatly promoted the development of Hubei's green economy efficiency. In particular, the development strategy of "two fundamental changes" proposed by the Fifth Plenary Session of the 14th Central Committee in 1995 has the greatest 
impact on the efficiency of Hubei's green economy(4), indicating that the intensive development approach has been valued and implemented in our province. At this stage, the green economy efficiency of Hubei Province only showed a slight decline in 1999, indicating that the Asian financial crisis has a certain impact on Hubei Province but to a limited extent.

The second stage: a small decline appears in 2002-2006. After joining the WTO, the efficiency of green economy in Hubei Province has declined to some extent, but its magnitude is not too large. The possible reason is the "time lag" of the interaction of economic variables. Subsequent research has confirmed this.

The third stage: It basically shows a trend of slow fluctuations in 2007-2015. In 2008, in response to a series of problems such as the rapid decline of China's economic growth rate and the negative growth of exports after the outbreak of the international financial crisis, the government launched a 4 trillion yuan investment plan to further expand domestic demand and promote steady and rapid economic growth. This policy has had a profound impact on the green economy efficiency of Hubei Province. At the same time, with the improvement of people's living standards, ordinary people have fully recognized the importance of environmental protection, and then "more and more severe" is the "new normal" of the government's environmental protection in China, which makes the green economy efficiency of Hubei Province gradually upgrade.

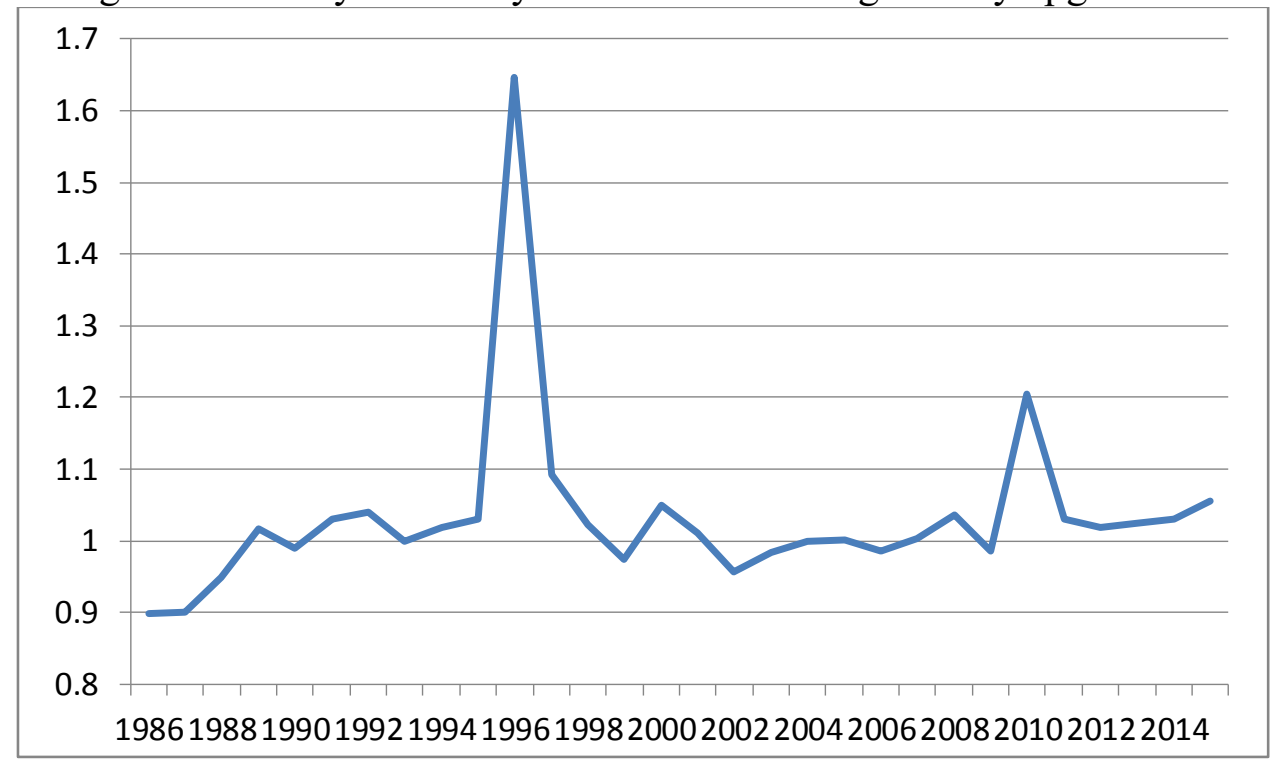

Figure 1 Evolution Trend of Green Economy Efficiency in Hubei Province

\section{Economic Opening Indicators}

This paper measures the degree of openness of Hubei's economy from the open situation of foreign capital and foreign trade, and analyzes the differences between the two degrees of economic indicators on the degree of "greenness" and "direction".

(1) The degree of foreign capital openness is measured by the proportion of the actual use of foreign direct investment in the GDP of Hubei Province. Since the actual use of foreign direct investment is expressed in US dollars, the middle price of the US dollar against the RMB exchange rate in the China Statistical Yearbook is converted into RMB and then divided by the GDP of Hubei. The indicator is expressed by $\mathrm{CO}$.

(2) The degree of openness of foreign trade is measured by the proportion of total import and export volume in Hubei's local GDP. The method of converting the total import and export volume expressed in US dollars into RMB is consistent with the openness of foreign investment. This indicator is expressed by TO.

\footnotetext{
(4) The first is the transformation of the economic system from the traditional planned economic system to the socialist market economic system. Second, the economic growth mode has changed from extensive to intensive.
} 


\section{Empirical Analysis of Foreign Trade Openness, Foreign Investment Openness and Green Economy Efficiency}

\section{Stationarity Test}

In order to avoid "pseudo-regression phenomena", a stationary test must be performed before regression analysis of time series economic variables. In this paper, the ADF unit root test method is used to test the stability of Hubei's green economy efficiency, foreign trade dependence and foreign capital dependence. The test results are shown in Table 3.

Table 3 ADF Unit Root Test Results of Variables

\begin{tabular}{|c|c|c|c|c|}
\hline Variable & Test form $(\mathrm{C}, \mathrm{T}, \mathrm{K})$ & ADF statistics & $\begin{array}{c}\text { Accompanying } \\
\text { an introduction }\end{array}$ & Conclusion \\
\hline SE & $(0,0,1)$ & -0.021559 & 0.6670 & Non-stationary \\
\hline CO & $(\mathrm{C}, 0,1)$ & -2.457699 & 0.1362 & Non-stationary \\
\hline TO & $(\mathrm{C}, 0,0)$ & -2.393417 & 0.1522 & Non-stationary \\
\hline $\mathrm{D}(\mathrm{SE})$ & $(0,0,0)$ & $-8.259806^{* * *}$ & 0.0000 & Stationary \\
\hline $\mathrm{D}(\mathrm{CO})$ & $(\mathrm{C}, 0,1)$ & $-3.532036^{* *}$ & 0.0148 & Stationary \\
\hline $\mathrm{D}(\mathrm{TO})$ & $(\mathrm{C}, 0,0)$ & $-4.581312^{* * *}$ & 0.0011 & Stationary \\
\hline
\end{tabular}

Note: (1)The $\mathrm{C}, \mathrm{T}$, and $\mathrm{K}$ in the unit root test form $(\mathrm{C}, \mathrm{T}, \mathrm{K})$ respectively represent constant terms, time trend terms and subsequent orders.

(2) $* * *$, and $* * *$ respectively indicate the significance level of $10 \%, 5 \%$, and $1 \%$.

(3) $\mathrm{D}(\mathrm{SE}), \mathrm{D}(\mathrm{CO})$, and $\mathrm{D}(\mathrm{TO})$ respectively represent the first-order difference of the original variables.

The test results show that the original data of Hubei's economic green economy efficiency, capital openness and trade openness are all unstable sequences, but the first-order difference sequences of the three variables are stationary sequences. The first-order difference terms of SE and TO pass the test at the $1 \%$ significance level, and the first-order difference term of CO passes the test at the 5\% significance level, indicating that all three economic variables are first-order single-order sequences. Thus, the cointegration relationship between these three variables can be further tested and also meets the VAR modeling requirements.

\subsection{Determination of the Optimal Lag Period}

The SE, CO and TO were selected to construct a 3-dimensional vector autoregressive model. The five ${ }^{(5)}$ most common lag period test criteria included in the measurement software EViews were used to determine the most lag period of the VAR model. The results are shown in Table 4:

Table 4 VAR Model Lag Order Selection Results

\begin{tabular}{|c|c|c|c|c|c|c|}
\hline Lag & LogL & LR & FPE & AIC & SC & HQ \\
\hline 0 & 184.6650 & NA & $4.65 \mathrm{e}-10$ & -12.97607 & -12.83334 & -12.93244 \\
\hline 1 & 224.2090 & 67.78962 & $5.27 \mathrm{e}-11$ & -15.15778 & $-14.58684^{*}$ & -14.98324 \\
\hline 2 & 238.0491 & $20.76022^{*}$ & $3.83 \mathrm{e}-11^{*}$ & $-15.50351^{*}$ & -14.50435 & $-15.19806^{*}$ \\
\hline
\end{tabular}

Note: * indicates the appropriate lag order judged by the relevant criteria

From the test results in Table 4, it can be found that the optimal lag period of the four criteria selected in the five test criteria is 2 , and the optimal lag period of the visible VAR model is 2 , so the $\operatorname{VAR}(2)$ model is established in this paper.

\section{Stability Test}

The AR eigenvalue method is used to test the stability of the VAR model in this paper. If the reciprocal of the AR root of the tested VAR model is less than 1, that is, it is located in the unit circle, indicating that the VAR model is stable and can perform impulse response function analysis and analysis of variance. The test results are shown in Table 5 and Figure 2.

\footnotetext{
(5) LR likelihood ratio test statistic, FPE final prediction error, AIC information criterion, SC information criterion, and HQ information
} 
Table 5 Characteristic Root Test Table

\begin{tabular}{|c|c|}
\hline Root & Modula \\
\hline 0.781732 & 0.781732 \\
\hline $0.503876-0.517851 \mathrm{i}$ & 0.722538 \\
\hline $0.503876+0.517851 \mathrm{i}$ & 0.722538 \\
\hline 0.615253 & 0.615253 \\
\hline$-0.319702-0.266272 \mathrm{i}$ & 0.416065 \\
\hline$-0.319702+0.266272 \mathrm{i}$ & 0.416065 \\
\hline
\end{tabular}

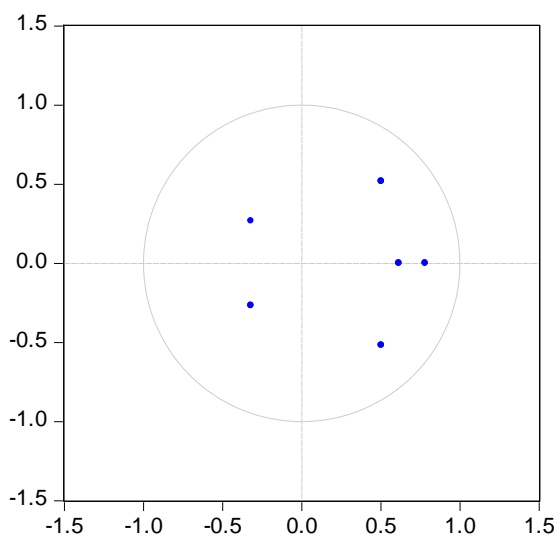

Figure 2 Reciprocal Distribution of the Eigenvalues

It can be seen from Table 5 and Figure 2 that the reciprocal of the model of the AR root of the tested VAR model is less than 1, and the reciprocal of all the roots is within the unit circle, indicating that the VAR model is stable, so the above three economic variables in Hubei Province can be establish a model of VAR(2) and perform impulse response and analysis of variance.

\subsection{Cointegration Test}

According to the ADF unit root test, the three variables SE, TO and CO are first-order single integer variables, namely:

$$
\mathrm{SE} \sim \mathrm{I}(1), \mathrm{TO} \sim \mathrm{I}(1), \mathrm{CO} \sim \mathrm{I}(1)
$$

The Johansen maximum likelihood test is used to test the covariance relationship of the above three variables. Generally, there are two kinds of Johansen test methods: trace statistic cointegration test and maximum eigenvalue statistic cointegration test. The test results are shown in Figure 6 and Figure 7, respectively.

Table 6 Trace Statistics Cointegration Test Results

\begin{tabular}{|c|c|c|c|c|}
\hline $\begin{array}{c}\text { Number of Coint egration } \\
\text { equation }\end{array}$ & Characteristic root & $\begin{array}{c}\text { Trace } \\
\text { statistics }\end{array}$ & Threshold & $\begin{array}{c}\text { Incidental } \\
\text { probability }\end{array}$ \\
\hline $0^{*}$ & 0.690563 & 51.94749 & 35.19275 & 0.0004 \\
\hline Up to $1 *$ & 0.382573 & 21.44949 & 20.26184 & 0.0342 \\
\hline Up to 2 & 0.290210 & 8.912447 & 9.164546 & 0.0558 \\
\hline
\end{tabular}

Table 7 Maximum Eigenvalue Statistic Cointegration Test Results

\begin{tabular}{|c|c|c|c|c|}
\hline $\begin{array}{c}\text { Number of } \\
\text { Cointegration } \\
\text { equation }\end{array}$ & $\begin{array}{c}\text { Characteristic } \\
\text { root }\end{array}$ & $\begin{array}{c}\text { Maximum } \\
\text { eigenvalue statistic }\end{array}$ & Threshold & $\begin{array}{c}\text { Incidental } \\
\text { probability }\end{array}$ \\
\hline $0^{*}$ & 0.690563 & 30.49799 & 22.29962 & 0.0029 \\
\hline Up to 1 & 0.382573 & 12.53705 & 15.89210 & 0.1569 \\
\hline Up to 2 & 0.290210 & 8.912447 & 9.164546 & 0.0558 \\
\hline
\end{tabular}

It can be seen from Table 6 and Table 7 that at the 5\% significance level, the trace statistic cointegration test accepts the assumption of up to two co-integration equations, and the maximum 
eigenvalue statistic co-integration test accepts at most one and two. The assumption of co-integration relationship, the test result of the co-integration of the trace statistic and the maximum eigenvalue statistic is different. The only cointegration relationship between foreign capital openness, foreign trade openness and green economy efficiency cannot be determined, but the existence of a cointegration relationship between the three variables is determinable, indicating that there is a long-term equilibrium relationship between the three variables.

\subsection{Granger Causality Test}

The causal relationship between variables is complicated, so the relationship between Granger causality test should be investigated to see if it is suitable to use the VAR model based on data generation process.

Table 8 Granger Causality Test Results

\begin{tabular}{|c|c|c|c|c|}
\hline Null hypothesis & $\begin{array}{c}\text { Chi-square } \\
\text { statistic }\end{array}$ & $\begin{array}{c}\text { Degree } \\
\text { of } \\
\text { freedom }\end{array}$ & $\begin{array}{c}\text { Incidental } \\
\text { probability }\end{array}$ & conclusion \\
\hline TO is not the Granger reason for SE & 8.597544 & 2 & $0.0136^{* *}$ & refuse \\
\hline CO is not the Granger reason for SE & 0.976433 & 2 & 0.6137 & accept \\
\hline $\begin{array}{c}\text { TO and CO are not the Granger reasons for SE } \\
\text { at the same time }\end{array}$ & 13.32371 & 4 & $0.0098^{* * *}$ & refuse \\
\hline SE is not the Granger reason for TO & 0.557828 & 2 & 0.7566 & accept \\
\hline CO is not the Granger reason for TO & 10.38733 & 2 & $0.0056^{* * *}$ & refuse \\
\hline $\begin{array}{c}\text { SE and CO are not the Granger reasons for TO } \\
\text { at the same time }\end{array}$ & 10.40159 & 4 & $0.0342^{* *}$ & refuse \\
\hline $\begin{array}{c}\text { SE is not the Granger reason for CO } \\
\text { TO is not the Granger reason for CO }\end{array}$ & 2.281104 & 2 & 0.3196 & accept \\
\hline $\begin{array}{c}\text { SE and TO are not the Granger reasons for CO } \\
\text { at the same time }\end{array}$ & 3.592717 & 4 & 0.4639 & accept \\
\hline
\end{tabular}

It can be seen from Table 8 that under the significant level of 5\% or even $1 \%$, the openness of foreign trade is the Granger cause of Hubei's green economy efficiency; the combination of foreign trade openness and foreign investment openness is also the Granger reason for Hubei's green economy efficiency. The openness of foreign capital is the Granger reason for the openness of foreign trade; the combination of the two factors of green economy efficiency and foreign capital openness is also the Granger reason for foreign trade openness.

\subsection{Impulse Response Function}

This paper mainly studies the impact of foreign trade openness and foreign capital openness on Hubei's green economy efficiency. Figures 3 and 4 only reflect the impulse response of foreign trade openness and foreign capital openness to green economy efficiency, and the three variables are impacted by themselves. The effects and other interactions of the impulse response function are not listed here. At the same time, in order to reflect the long-term relationship between variables as much as possible, a 20-year impulse response function graph was used. 
Response to CholeskyOne S.D. Innovations \pm 2 S.E.

Response of SE to TO

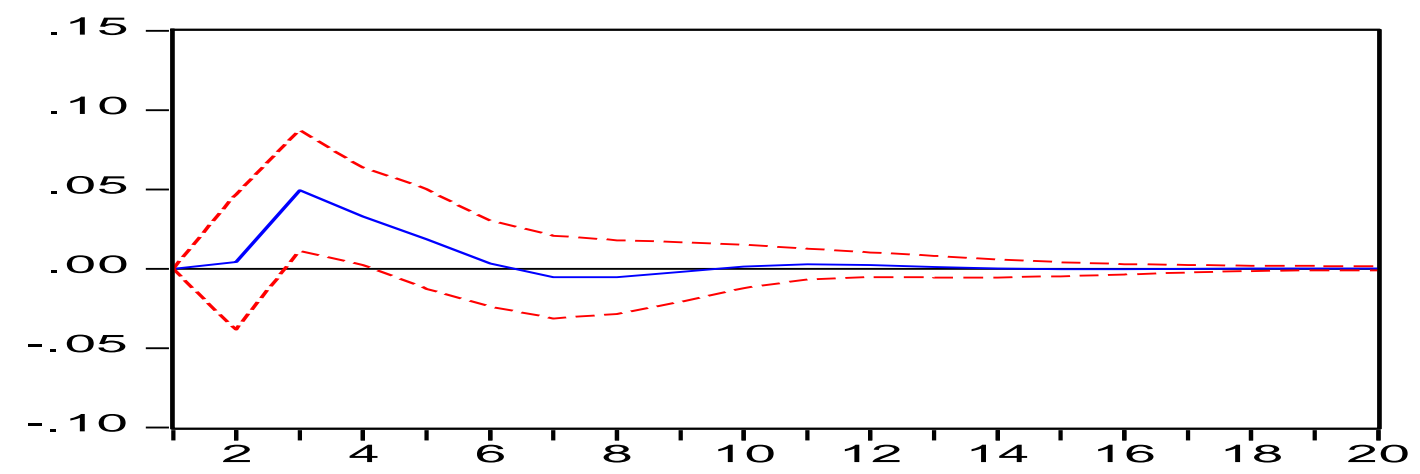

Response of TO to TO

.020

.020

.015

.015

.010

.010

.005

.005

.000

.000

$-.005$

$-.005$

$-.010$

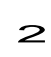

4

6

8

10

12

14

16

18

20

Response of 60 to TO

.006

.004

.002

.000

$-.002$

$-.004$

20

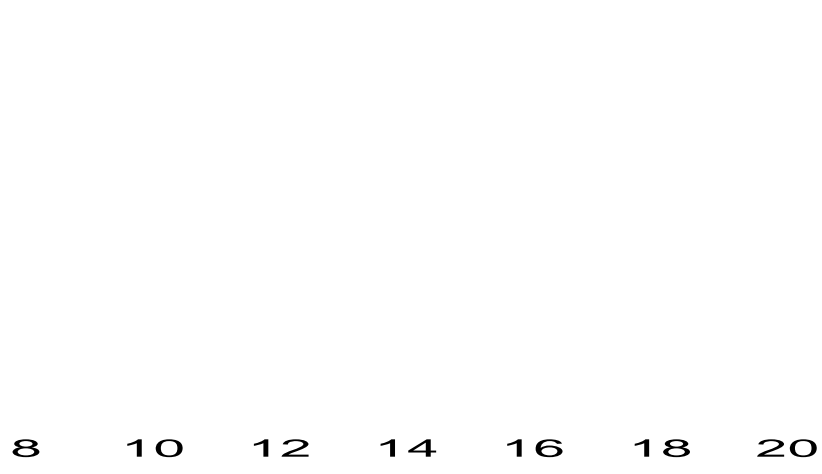

negative intluence gradually weakened. By the tourth year, it turned trom a negative intluence to a positive influence (0.0294), and then its positive direction gradually weakened. In the eighth year, it turned into a negative influence, and its influence degree tended to converge after the 12th year. 


\section{Analysis of Variance Decomposition}

Table 9 Green Economic Efficiency Variance Decomposition Analysis Table

\begin{tabular}{|c|c|c|c|c|}
\hline $\begin{array}{c}\text { Forecast } \\
\text { period }\end{array}$ & $\begin{array}{c}\text { Standard deviation } \\
\text { (S.E.) }\end{array}$ & $\begin{array}{c}\text { Green economy } \\
\text { efficiency }\end{array}$ & $\begin{array}{c}\text { Foreign trade } \\
\text { openness }\end{array}$ & $\begin{array}{c}\text { Foreign investment } \\
\text { openness }\end{array}$ \\
\hline 1 & 0.112374 & 100.0000 & 0.000000 & 0.000000 \\
\hline 2 & 0.117214 & 97.17735 & 0.130198 & 2.692456 \\
\hline 3 & 0.127816 & 82.72123 & 14.99651 & 2.282254 \\
\hline 4 & 0.135265 & 73.91138 & 19.34018 & 6.748446 \\
\hline 5 & 0.139890 & 69.48616 & 19.85587 & 10.65797 \\
\hline 6 & 0.141809 & 68.54377 & 19.37309 & 12.08314 \\
\hline 7 & 0.142168 & 68.49140 & 19.41894 & 12.08966 \\
\hline 8 & 0.142417 & 68.25727 & 19.49447 & 12.24826 \\
\hline 9 & 0.142748 & 68.00189 & 19.42567 & 12.57244 \\
\hline 10 & 0.142975 & 67.89641 & 19.37227 & 12.73132 \\
\hline 11 & 0.143068 & 67.86838 & 19.38499 & 12.74663 \\
\hline 12 & 0.143097 & 67.85387 & 19.40465 & 12.74148 \\
\hline 13 & 0.143104 & 67.84760 & 19.40903 & 12.74337 \\
\hline 14 & 0.143104 & 67.84738 & 19.40894 & 12.74367 \\
\hline 15 & 0.143106 & 67.84565 & 19.40945 & 12.74490 \\
\hline 16 & 0.143111 & 67.84170 & 19.40888 & 12.74941 \\
\hline 17 & 0.143116 & 67.83865 & 19.40756 & 12.75378 \\
\hline 18 & 0.143119 & 67.83741 & 19.40683 & 12.75577 \\
\hline 19 & 0.143121 & 67.83708 & 19.40675 & 12.75617 \\
\hline 20 & 0.143121 & 67.83699 & 19.40682 & 12.75619 \\
\hline$I t$ & 6 & & & \\
\hline
\end{tabular}

It can be seen from the above table that in addition to its own influence, the fluctuation of Hubei's green economy efficiency (SE) is mainly caused by the fluctuation of foreign trade openness (TO). That is to say, in the economic opening indicators, the fluctuation of the proportion of total import and export to the GDP is the most important cause of fluctuations in regional green economy efficiency in Hubei Province. The impact of Hubei's foreign trade openness on economic efficiency fluctuations began from the second period, and the second period basically stabilized. The 12th to 20th periods basically remained at $19.4 \%$. After the 10th period, the degree of influence of foreign investment openness on the efficiency of green economy has also stabilized, staying at around $12.7 \%$.

\section{Conclusions and Policy Recommendations}

This paper uses the statistical data of Hubei Province from 1986 to 2015 to measure the green economy efficiency of Hubei, and applies the quantitative analysis method to study the influence of economic opening on the efficiency of green economy, and draws the following conclusions:

(1) There is a long-term stable equilibrium relationship between foreign trade openness, foreign investment openness and Hubei's green economic efficiency.

(2) The joint effect of foreign trade opening, foreign trade opening and foreign capital opening has promoted the growth of green economy efficiency in Hubei Province; foreign capital opening has promoted the growth of foreign trade openness.

(3) The development of foreign trade has a positive impact on the efficiency of green economy, while the use of foreign direct investment has the cyclical effect of negative and positive alternating "negative" and "positive". In terms of the extent of its impact, the influence of foreign trade is greater than the influence of foreign direct investment. The "pollution paradise hypothesis" was proved once again, that is, the foreign direct investment industry in Hubei has certain pollution.

Based on the above research conclusions, the following policy recommendations are proposed: 
(1) Develop foreign trade vigorously. Increase the competitiveness of Hubei's pillar industries in the global industrial chain and increase exports. It is necessary to speed up the upgrading of import and export trade growth mode and the transformation of export product structure, and strive to increase the proportion of capital-intensive products, especially technology-intensive goods in export commodities, and increase the "complexity" of Hubei's export commodities.

(2) Attract foreign investment selectively. Governments at all levels in Hubei should strictly examine and directly guide foreign direct investment projects and fields. When introducing foreign investment projects, governments at all levels in Hubei Province must strictly review and formulate "access criteria" for foreign investment projects and industries, and shift the main focus from the scale of foreign direct investment projects to the quality of foreign direct investment projects. For projects with high energy consumption and high pollution, we must resolutely put an end to it, actively introduce projects related to high-end manufacturing and production services, and make innovative use of foreign capital.

(3) In formulating economic open policies, we should comprehensively consider the two factors of "foreign trade" and "foreign investment", in order to form a "combination force" in the policy of opening up to the outside world. The above research shows that in the short term, foreign capital does not promote the improvement of green economy efficiency, but the foreign trade and the combined effect of foreign trade and foreign capital has greatly promoted the improvement of green economy efficiency. Therefore, policies at all levels should fully consider the two factors of "foreign trade" and "foreign investment" when introducing relevant policies, so that the two open policies promote each other and develop together, and ultimately promote the development of Hubei's green economy and make Hubei's economy move to a high level.

\section{Acknowledgement}

* Fund Project: Hubei Provincial Social Science Fund General Research Project "Measurement and Research on Green Total Factor Productivity in Hubei Province” (Project No.: 2017150)

\section{References}

[1] Gao Tiemei. Econometric Analysis Methods and Modeling: EViews Applications and Examples [M] Beijing: Tsinghua University Press, January 2006, 1st Edition

[2] E Huifang, Du Jinzhu. Measurement and Difference Analysis of Regional Ecological Efficiency in China Based on Super Efficiency DEA Model[J]. Studies in Finance and Economics, 2015(4): 55-63.

[3] Li Huaizheng. Environmental Regulation, Technological Progress and Export Trade Expansion [J]. International Trade Issues, 2011(12): 130-137.

[4] Liu Wei, Lu Liwei. Dynamic Analysis of Time Delay Effect of Foreign Direct Investment under the Framework of VAR Model[J]. Quantitative Economics of Economics and Technology, 2006, 23(10): 101-110

[5] Shan Haojie. Re-estimation of China's Capital Stock K: 1952-2006 [J]. Journal of Quantitative and Technical Economics, 2008(10): 17-31

[6] Wang Xuhui, Xu Jian. Efficiency Evaluation of China's Logistics Listed Companies Based on Super Efficiency CCR-DEA Model[J]. Finance and Trade Research, 2009, 20(6): 117-124.

[7] Liu Hong, Li Shuwei. Research on the Impact of FDI on China's Economic Growth and Employment—Based on VAR Model[J]. International Trade Problem, 2013(4): 105-114.

[8] Jia Lili, Wang Jia, Hu Mengze. Research on the Relationship between Industrial Economic Development and Environmental Pollution Based on VAR Model[J]. Industrial Technology \& Economy, 2017, 36(2): 43-49.

[9] Ding Zhengliang, Ji Chengjun. An Empirical Study of China's Import, Export, Real Exchange Rate and Economic Growth Based on VAR Model[J]. International Trade Problem, 2014(12): 91-101. 